\title{
A Psychological Study on the Effectiveness of Marriage Enrichment Training through PAIRS Method in Marital Conflicts
}

\author{
Mahshid Alsadat Keyhandoost ${ }^{1,2}$, Ebrahim Namani ${ }^{3}$ \\ ${ }^{1}$ Department of Psychology, Faculty of Humanities, Neyshabur Branch, Islamic Azad University, Neyshabur, Iran \\ ${ }^{2}$ Department of Psychological Sciences, Faculty of Humanities, Neyshabur Branch, Islamic Azad University, Neyshabur, Iran \\ ${ }^{3}$ Department of Educational Sciences, Hakim Sabzevari University, Sabzevar, Iran \\ Email: a.namani@hsu.ac.ir
}

How to cite this paper: Keyhandoost, $M$. A., \& Namani, E. (2017). A Psychological Study on the Effectiveness of Marriage Enrichment Training through PAIRS Method in Marital Conflicts. Advances in Applied Sociology, 7, 172-180.

https://doi.org/10.4236/aasoci.2017.74011

Received: December 29, 2016

Accepted: April 16, 2017

Published: April 19, 2017

Copyright (c) 2017 by authors and Scientific Research Publishing Inc. This work is licensed under the Creative Commons Attribution International License (CC BY 4.0).

http://creativecommons.org/licenses/by/4.0/

\begin{abstract}
This study aims to investigate the effectiveness of marriage enrichment training through PAIRS method in marital conflicts of married female students. The present research is an applied study in terms of purpose. Also, in terms of data collection method, it is a pretest-posttest quasi-experimental study with a nonequivalent control group. The statistical population comprised all married female students in Neyshabour Islamic Azad University, who participated in this study in the autumn of 2015. The sample was selected through purposive and available sampling method. From among the married couples, 30 married female students were chosen purposefully and were randomly assigned into two experimental (15 subjects) and control (15 subjects) groups. The data were collected through Marital Conflict Questionnaire by Sanaei (2000). The data were analyzed using the analysis of covariance test. The findings demonstrated that marriage enrichment training through the PAIRS method is effective in improving marital conflicts $(P<0.05)$. Based on the research findings, it can be concluded that marriage enrichment training through the PAIRS method can reduce marital conflicts in married female students.
\end{abstract}

\section{Keywords}

Marriage Enrichment Training through the PAIRS Method, Marital Conflicts, Married Female Students

\section{Introduction}

Marital conflict is considered as the interaction between couples who have con- 
flicting interests, views and beliefs (Srong, Devault, \& Cohen, 2011). 61\% of divorced people have reported excessive conflict as one of the reasons for their divorce (Troupe, 2008). Some theories believe that conflict in family life is a natural event and in most cases, it is considered as an inevitable phenomenon that can be seen in all family relationships (Faircloth, 2012).

Gottman (1999) divides marital conflict into two types of solvable and persistent conflicts. Solvable conflicts, as its name implies, can be solved throughout life. But persistent conflicts become part of people's lives forever; for example, a family that cannot decide about its travel destination on vacation is involved in solvable conflict. In such a situation, family members finally reach a participatory decision using the correct techniques of conflict resolution and the conflict is resolved. But persistent conflicts have a deep root in disagreements over key issues such as values, roles and personality traits. These conflicts are constantly manifested in family atmosphere and are hardly changeable if not to say unchangeable. Marital conflict has a direct relationship with the variables like divorce (Riggio \& Valenzuela, 2011), mental disorders in children (Blodgett, Schaefer, \& Haugen, 2013) and mental and emotional pressure in couples (LucasThompson, 2012) and an inverse relationship with the variables such as psychological adjustment of children (Oh, Lee, \& Park, 2011).

Based on the foregoing and with regard to destructive effects of marital conflicts on the whole family, we seek in this study to find a factor that helps to improve the spousal relationship and reduce marital conflicts. Among the methods used for the promotion of marital relations are enrichment methods. In this study, marriage enrichment through PAIRS (Practical Application of Intimate Relationship Skills) method has been used. Enrichment is a movement for the growth of marital relationship and leads to strengthening of the relationship through creating goals and directions for marriage (Miri, Alizadeh, Mo'asheri, 'Ataei, \& Moudi, 2015). Marriage enrichment movement has a large share in the growth and development of millions of couples. Generally, marriage enrichment program is active in the field of training communications to couples, resolving conflicts between them, financial management, marital satisfaction, couples' activity at leisure time, religious beliefs of each side, the relationship between children and parents, the relationship between family and friends, couples' realistic expectations of each other, sexual expectations and the role of relatives in marital life. This program provides the couples with trainings in these fields. These trainings largely include teaching communicative skills, creating satisfaction with the relationship, active listening, skills to control conflicts, problem-solving skills, learning assertive behavior, controlling emotions, raising awareness, couples' understanding of self, others and common life and strengthening emotional relationships between them (Owliya, 2006).

Based on the studies conducted, PAIRS enrichment method has the greatest amount of effectiveness and desirability (Isanezhad, Ahmadi, \& E’temadi, 2010). This method helps individuals improve their relationships and at the same time preserve the quality of these relationships over time. This approach is a training 
model to teach skills for the improvement of satisfaction and stability of couple relationship. In this model, couples learn how to be receptive and sympathetic towards each other and avoid prejudice (Nazari, Taherirad, \& Asadi, 2013). More specifically, marriage enrichment is a training approach to improve the relationships between couples and its purpose is to help them become aware of themselves and their spouse, explore the feelings and thoughts of the spouse and develop empathy, intimacy, effective communication and marital satisfaction (Manne \& Badr, 2008). However, the researcher in this study intends to evaluate the impact of marriage enrichment training through the PAIRS method on marital conflicts among student couples and seeks to answer the question as to whether marriage enrichment training using the PAIRS method is effective in the improvement of marital conflicts of student couples.

There is little attention given to research on the effectiveness of marriage enrichment training through PAIRS method in marital conflicts in Iran. Therefore, the present study tries to fill to propose a framework on the mentioned topic in Iran.

\section{Methods}

The present research is an applied study in terms of purpose. Also, in terms of data collection method, it is a pretest-posttest quasi-experimental study with a nonequivalent control group. The statistical population consists of all married female students in Neyshabour Islamic Azad University in the year 2015. 30 married female students were selected through purposive and available sampling method and were randomly assigned into two experimental (15 subjects) and control (15 subjects) groups. The interventions were conducted only on the subjects of the experimental group. In this study, Marital Conflict Questionnaire by Baqer Sanaei was employed to collect the data.

The Questionnaires include 5 point Likert type questions scored from 1 - 5. The pretest and posttest have been implemented with 9 months delay.

\section{Marital Conflict Questionnaire}

This scale includes 42 questions and is used to measure marital conflict based on clinical experiences and has been developed by Sanaei (2000). This questionnaire evaluates seven dimensions of marital conflicts including reduction in cooperation, reduction in sexual intercourse, increase in emotional reactions, increase in attracting the support of child, increase in personal relationship with one's relatives, reduction in family relation with one's spouse's relatives and friends and separation of financial affairs from each other. This scale enjoys good content validity. In the stage of analyzing the test materials, after preliminary implementation and calculation of the correlation of each question with the whole questionnaire and its scales, 13 questions out of 55 questions were eliminated (Sanaei, 2000). In the study carried out by Khazaei (2006), the scores of all components of Marital Conflict Questionnaire ranging from 0.31 to 0.82 had a significant correlation with the total score of marital conflict at the level of 0.01 . 
Further, Dehqan (2001) has conducted a study on a group of 30 people for standardization of marital conflict questionnaire and has used Cronbach's alpha method for the following cases: 0.71 for the whole questionnaire, 0.73 for reduction in cooperation, 0.60 for reduction in sexual intercourse, 0.74 for increase in emotional reactions, 0.81 for increase in attracting the support of child, 0.65 for increase in personal relationship with one's relatives, 0.81 for reduction in family relation with one's spouse's relatives and friends and 0.69 for separation of financial affairs from each other.

\section{Implementation Method}

After preliminary study and preparation of tools and selection of 30 married female students through purposive and available sampling, the subjects were divided into two experimental and control groups. In a letter, the sample was asked to provide necessary cooperation regarding the study and the participants were assured that the data obtained from the study is confidential and will not be made available to others. The inclusion criteria were as follows: 1) The women participating in the study should be married for more than 3 years; 2) the women are not dissatisfied with their martial relationships and 2) they should not be in another psychological treatment group. After implementing the interventions on the experimental group, the posttest was conducted and the data was analyzed.

The educational content of sessions was as follows: At the beginning of each session, a summary of the discussions of the previous session was presented and the members offered their opinions about the previous session. At the end of each session, conclusion of the discussions was provided. Objectives of the training sessions are as follows (Table 1).

\section{Data Analysis Method}

The data obtained from the scores of this study were analyzed at two descriptive and inferential levels. At the descriptive level, indicators such as mean and standard deviation were used and at the inferential level, covariance analysis method through SPSS-22 statistical software was applied.

\section{Findings}

To describe the data relating to the sample, central indices and dispersion of the research variables were initially calculated as follows (Table 2).

In this study, multivariate analysis of covariance test has been applied because of more appropriateness and compatibility with the research hypotheses. It should be noted that before performing this test, the assumptions of this method were investigated by Box and Levene's tests. According to Box's M test which has not been significant for each of the variables, the condition of homogeneity of variance-covariance matrices has been properly observed (F $=0.674, P=$ 0.720 ). Additionally, the significance level of Levene's test in the variable of marital conflicts was $(\mathrm{F}=1.628, P=0.212)$. With regard to the numbers and figures 
Table 1. Framework of the training sessions.

\begin{tabular}{|c|c|c|}
\hline Session & Overall objective & Behavioral objective \\
\hline 1 & $\begin{array}{l}\text { Establishing } \\
\text { communication }\end{array}$ & $\begin{array}{l}\text { Training how to learn trust-building in the establishment } \\
\text { of intimacy, training how to listen and speak effectively } \\
\text { and levels of communication establishment }\end{array}$ \\
\hline 2 & Problem-solving & $\begin{array}{l}\text { Training the issues such as learning how to produce negative } \\
\text { reaction to the behavior of the spouse through directing the dialogue }\end{array}$ \\
\hline 3 & $\begin{array}{l}\text { Clarifying mental } \\
\text { imaginations }\end{array}$ & $\begin{array}{l}\text { Training the issues like awareness of the mind-reading skill which is } \\
\text { one of the PAIRS skills plus untold mental imaginations and hidden } \\
\text { expectations of the spouse }\end{array}$ \\
\hline 4 & Personal history & $\begin{array}{l}\text { Training the genealogical depiction of three generations of the family, } \\
\text { remembering and expressing the previous painful, sad and suppressed } \\
\text { experiences for each other }\end{array}$ \\
\hline 5 & $\begin{array}{l}\text { Emotional retraining } \\
\text { and emotional bond }\end{array}$ & $\begin{array}{l}\text { Training the issue of coping with old painful experiences and receiv- } \\
\text { ing positive feedback from the spouse and other group members }\end{array}$ \\
\hline 6 & $\begin{array}{l}\text { Sexual pleasure and } \\
\text { sexual performance }\end{array}$ & $\begin{array}{l}\text { Training the issues like removal of barriers to enjoyment, training the } \\
\text { skills for relationship enrichment and obtaining pleasure in relations } \\
\text { between spouses, training exercises to activate the } \\
\text { five senses and also directed messages through which couples } \\
\text { exchange enjoyable contacts }\end{array}$ \\
\hline 7 & $\begin{array}{l}\text { Conclusion of } \\
\text { a contract }\end{array}$ & $\begin{array}{l}\text { Training the issue of satisfaction with the division of participation } \\
\text { rate, the effect of one's accountability on the group }\end{array}$ \\
\hline 8 & $\begin{array}{l}\text { Clarifying } \\
\text { expectations and } \\
\text { finally, summing up } \\
\text { the previous sessions }\end{array}$ & $\begin{array}{l}\text { Training the issue of couples' readiness to share power and } \\
\text { responsibility, group discussion at the end of the session about the } \\
\text { changes made in individuals due to participation in the sessions, } \\
\text { reviewing the evidence relating to the change in the group, summing } \\
\text { up the sessions and conclusion, implementation of the posttest, } \\
\text { thanks and appreciation to the members fo } \\
\mathrm{r} \text { their participation in the session }\end{array}$ \\
\hline
\end{tabular}

Table 2. Descriptive indicators between the experimental $(\mathrm{N}=15)$ and control $(\mathrm{N}=15)$ groups in the variable of marital conflict.

\begin{tabular}{ccccccc}
\hline \multirow{2}{*}{$\begin{array}{c}\text { Main } \\
\text { variable }\end{array}$} & Component & $\begin{array}{c}\text { Statistical } \\
\text { indicator }\end{array}$ & Pretest & Posttest & Pretest & Posttest \\
& Reduction in cooperation & Mean & 18.46 & 14.06 & 19.06 & 18.46 \\
& SD & 1.06 & 0.70 & 0.70 & 0.52 \\
& $\begin{array}{c}\text { Reduction in } \\
\text { sexual intercourse }\end{array}$ & Mean & 18.73 & 14.53 & 18.60 & 18.33 \\
& SD & 0.79 & 0.74 & 1.35 & 1.34 \\
& $\begin{array}{c}\text { Increase in attracting the } \\
\text { Marital } \\
\text { conflict }\end{array}$ & Mean & 18.13 & 14.06 & 18.13 & 17.73 \\
& $\begin{array}{c}\text { Increase in personal } \\
\text { relationship with one's } \\
\text { relatives }\end{array}$ & Mean & 20.60 & 14.86 & 20.53 & 19.86 \\
& $\begin{array}{c}\text { Reduction in family } \\
\text { relation with one's spouse's } \\
\text { relatives and friends }\end{array}$ & SD & 1.29 & 0.52 & 1.24 & 1.12 \\
& $\begin{array}{c}\text { Sean } \\
\text { Separation of financial }\end{array}$ & 20.53 & 15.86 & 19.13 & 18.86 \\
affairs from each other & Mean & 22.93 & 16.66 & 22.06 & 21.40 \\
& SD & 1.66 & 1.44 & 1.75 & 1.68 \\
& $\begin{array}{c}\text { Increase in emotional } \\
\text { reactions }\end{array}$ & Mean & 38.86 & 32.06 & 38.73 & 38.13 \\
& SD & 0.99 & 5.09 & 1.33 & 1.30 \\
\hline
\end{tabular}


mentioned, assumptions of the covariance analysis test have been observed.

In order to assess the research hypothesis indicating the effectiveness of marriage enrichment training through the PAIRS method in marital conflicts of student couples, analysis of covariance method was used whose results are as follows (Table 3).

Table 3 displays the results obtained from the analysis of covariance test regarding the subscales of marital conflicts in the groups under study. The above table shows that the influence of training on the subscales of marital conflict (reduction in cooperation, reduction in sexual intercourse, increase in attracting the support of child, increase in personal relationship with one's relatives, reduction in family relation with one's spouse's relatives, separation of financial affairs from each other and increase in emotional reactions) of the subjects is statistically significant $(P<0.01)$. Besides, the rate of the effect of the intervention is $93 \%$ for reduction in cooperation, $87 \%$ for reduction in sexual intercourse, $90 \%$ for increase in attracting the support of child, $87 \%$ for increase in personal relationship with one's relatives, $78 \%$ for reduction in family relation with one's spouse's relatives, $87 \%$ for separation of financial affairs from each other and $50 \%$ for increase in emotional reactions. In other words, the subjects of the experimental group have had $50 \%$ to $93 \%$ reduction in marital conflicts compared

Table 3. Analysis of covariance difference between the average scores of marital conflict on the experimental and control groups.

\begin{tabular}{|c|c|c|c|c|c|c|c|}
\hline Variable & Status & $\begin{array}{l}\text { Degree of } \\
\text { freedom }\end{array}$ & $\begin{array}{c}\text { Mean } \\
\text { squares }\end{array}$ & $\mathbf{F}$ & $\begin{array}{c}\text { Significance } \\
\text { level }\end{array}$ & $\begin{array}{l}\text { Impact } \\
\text { factor }\end{array}$ & $\begin{array}{c}\text { Statistical } \\
\text { power }\end{array}$ \\
\hline $\begin{array}{l}\text { Reduction in } \\
\text { cooperation }\end{array}$ & $\begin{array}{c}\text { Group } \\
\text { membership }\end{array}$ & 1 & 98.78 & 290.85 & 0.000 & 0.93 & 1.00 \\
\hline $\begin{array}{c}\text { Reduction in } \\
\text { sexual } \\
\text { intercourse }\end{array}$ & $\begin{array}{c}\text { Group } \\
\text { membership }\end{array}$ & 1 & 85.52 & 148.25 & 0.000 & 0.87 & 1.00 \\
\hline $\begin{array}{l}\text { Increase in } \\
\text { attracting the } \\
\text { support of } \\
\text { child }\end{array}$ & $\begin{array}{c}\text { Group } \\
\text { membership }\end{array}$ & 1 & 66.79 & 200.04 & 0.000 & 0.90 & 1.00 \\
\hline $\begin{array}{l}\text { Increase in } \\
\text { personal } \\
\text { relationship } \\
\text { with one's } \\
\text { relatives }\end{array}$ & $\begin{array}{c}\text { Group } \\
\text { membership }\end{array}$ & 1 & 108.48 & 184.01 & 0.000 & 0.87 & 1.00 \\
\hline $\begin{array}{l}\text { Reduction in } \\
\text { family } \\
\text { relation with } \\
\text { one's spouse's } \\
\text { relatives }\end{array}$ & $\begin{array}{c}\text { Group } \\
\text { membership }\end{array}$ & 1 & 98.16 & 75.86 & 0.000 & 0.78 & 1.00 \\
\hline $\begin{array}{l}\text { Separation of } \\
\text { financial } \\
\text { affairs from } \\
\text { each other }\end{array}$ & $\begin{array}{c}\text { Group } \\
\text { membership }\end{array}$ & 1 & 141.17 & 144.35 & 0.000 & 0.87 & 1.00 \\
\hline $\begin{array}{c}\text { Increase in } \\
\text { emotional } \\
\text { reactions }\end{array}$ & $\begin{array}{c}\text { Group } \\
\text { membership }\end{array}$ & 1 & 106.76 & 21.33 & 0.000 & 0.50 & 0.99 \\
\hline
\end{tabular}


to the control group. Hence, the research hypothesis stating that marriage enrichment training through the PAIRS method can lead to the improvement of marital conflicts in student couples was confirmed.

\section{Discussion}

This study aims to investigate the effectiveness of marriage enrichment training using the PAIRS method in marital conflicts of student couples. The overall results suggested that marriage enrichment training using the PAIRS method is effective in improving marital conflicts of couples and there is significant difference between the experimental and control groups in the component of marital conflict so that the scores of the marital conflict component in the experimental group compared to the control group showed a significant reduction in the posttest.

Findings of the present study are consistent with the results of the studies on the effectiveness of marital relationship enrichment in reducing marital conflict and its components, prevention of divorce, cognitive restructuring and emotion detection (Herbert \& Irene, 2013; Robin \& Hershey, 2010), reduction in financial problems, learning conflict management, prevention of couples' depression (Alvan, 2004), intimacy, mutual understanding, sharing positive and negative emotions with each other, reduction in the prevalence and incidence of marital distress, marital satisfaction, better communication and problem-solving behaviors, happier life and overcoming negative thoughts and behaviors (Berger \& Hannah, 2013), enhanced mental health, agreement and consultation in marital issues, improved self-esteem and general adjustment (Blanchard, 2008) and marital interaction and adaptation since learning problem-solving skills and conflict resolution causes a reduction in negative behavioral, emotional and attitudinal consequences resulting from unhealthy attitude or conflict and leads to reduced conflict and ultimately increased marital intimacy (Isanezhad, Ahmadi, \& E'temadi, 2010).

Thus, marriage enrichment training through the PAIRS method helps in identifying the strengths and weaknesses of one's relationship and solving the factors leading to conflict. This approach teaches the couples cognitive skills, problem-solving and conflict resolution, establishment of communication, codes of conduct and appropriate exchange and increases the rate of marital intimacy and reduces conflict. For example, if in the conditions of marital conflicts, the individual relationship of each couple with the relatives increases, the excessive presence of the original family physically or non-physically in the married life confuses the privacy of family relationships and boundaries of the married life with the outside. This issue leads to increased conflict between husband and wife. In this respect, marriage enrichment training through the PAIRS method causes that the couples have more relationship with their spouse instead of relationship with their original family (Brooks, Guerney, \& Mazza, 2001). Moreover, enrichment training prevents the escalation of conflict and subsequently involvement of the relatives and formation of hostility and improves attitudes, 
perceptions and ways of dealing with relatives and the people around. Therefore, it can be mentioned that the main purpose of this approach is to help in satisfying the basic needs of the family like love, kindness, belonging, security and pleasure. As a result, it is expected that this approach improve marital satisfaction; especially the skill of empathy causes the couples to help their spouse in satisfying his/her emotional and mental needs and leads to the creation of open, honest and intimate behaviors on the part of the spouse. In explaining these findings, it can be said that PAIRS marriage enrichment model helps the couples learn newer and more positive communication patterns through the proper tools given to them for solving their communication problems and in this way, their satisfaction with their marital life is improved.

\section{Conclusion}

Based on the foregoing, PAIRS enrichment program can be used as an appropriate program to increase satisfaction in marital life. But this study was faced with specific limitations including the failure to do the follow-up stage due to lack of access to participants after the implementation of the posttest. Thus, it is recommended that other researchers in such studies engage in the implementation of the follow-up stage. Since enrichment training is a preventive program and can prevent the escalation of marital conflicts, development of a center for providing such trainings is suggested.

\section{References}

Alvan, A. (2004). Hostile Volatile, Avoiding and Validating. Couple-Conflict Types: An Investigation of Guttmanns Couple Conflict Types. Personal Relationship, 10, 267-282.

Berger, R., \& Hannah, M. T. (2013). Preventive Approaches in Couple Therapy (pp. 391-420). Lillington, NC: Taylor and Francis.

Blanchard, O. (2008). Prediction of Marital Distress: A 5-Year Follow-Up. Journal of Insulting and Clinical Psychology, 40, 760-762.

Blodgett, E. H., Schaefer, M. K., \& Haugen, E. C. (2013). Connections between Marital Conflict and Adolescent Girls' Disordered Eating: Parent-Adolescent Relationship Quality as a Mediator. Journal of Child \& Family Studies, 22, 1-11.

Brooks, L. W., Guerney, J. B., \& Mazza, N. (2001). Relationship Enhancement Couples group Therapy. Journal Fan Social, 6, 25-42.

Dehqan, F. (2001). Comparing Marital Conflicts of Women Seeking Divorce and Women Referring to the Centers for Marital Counseling. MA Thesis in Counseling, Tehran: Tarbiat Moallem University.

Faircloth, B. (2012). Children and Marital Conflict: A Review. Case Makers, 6, 1-5.

Gottman, J. M. (1999). The Marriage Survival Kit: A Research-Based Matherapy. In R. Berger, \& H. Therese (Eds.), Preventive Approaches in Coutherapy (pp. 304-330). Philadelphia, PA: Brunner/Mazel.

Herbert, G., \& Irene, G. (2013). Family Therapy (8th ed., pp. 113-163). USA: Brooks Cole.

Holman, T. B., \& Jarvis, M. O. (2003). Hostile, Volatile, Avoiding, and Validating CoupleConflict Types: An Investigation of Gottman's Couple-Conflict Types. Personal Relationship, 10, 267-282. https://doi.org/10.1111/1475-6811.00049

Isanezhad, O., Ahmadi, A., \& E’temadi, O. (2010). Effectiveness of Relationship Enrich- 
ment in Improving the Quality of Marital Relationships of Couples. Journal of Behavioral Sciences, 4, 9-16.

Khazaei, M. (2006). Examining the Relationship between Communication Patterns and Marital Conflicts of Students in Tehran University. MA Thesis in Counseling, Tehran: Khatam University.

Lucas-Thompson, R. G. (2012). Associations of Marital Conflict with Emotional and Physiological Stress: Evidence for Different Patterns of Dysregulation. Journal of Research on Adolescence, 22, 704-721. https://doi.org/10.1111/j.1532-7795.2012.00818.x

Manne, S., \& Badr, H. (2008). Intimacy and Relationship Processes in Couples' Psychosocial Adaptation to Cancer. Cancer, 112, 2541-2455. https://doi.org/10.1002/cncr.23450

Miri, M. R., Alizadeh, M., Mo'asheri, N., 'Ataei, M., \& Moudi, M. (2015). Investigating the Impact of Relationship Enrichment Training Program on Marital Satisfaction and Adjustment of Infertile Couples. Journal of Health Literacy, 1, 54-60.

Nazari, A. M., Taherirad, M., \& Asadi, M. (2013). The Influence of Relationship Enrichment Program on Marital Adjustment of Couples. Journal of Family Counseling and Psychotherapy, 3, 527-542.

Oh, K. J., Lee, S., \& Park, S. H. (2011). The Effects of Marital Conflict on Korean Children's Appraisal of Conflict and Psychological Adjustment. Journal of Child and Family Studies, 20, 444-451. https://doi.org/10.1007/s10826-010-9411-6

Owliya, N. (2006). Investigating the Effect of Marriage Enrichment Training on Increased Satisfaction of Couples in Isfahan. MA Thesis, Isfahan: University of Isfahan.

Riggio, H. R., \& Valenzuela, A. M. (2011). Parental Marital Conflict and Divorce, Parent-Child Relationships, and Social Support among Latino American Young Adults. Personal Relationships, 18, 392-409. https://doi.org/10.1111/j.1475-6811.2010.01305.x

Robin, D. M., \& Hershey, A. M. (2010). Relationship Education for Unmarried Couples with Children: Parental Responses to the Building Strong Families Project. Journal of Couple \& Relationship Therapy: Innovations in Clinical and Educational Interventions, 9, 161-180. https://doi.org/10.1080/15332691003694919

Sanaei, B. (2000). Measurement Scales of Family and Marriage. Tehran: Be'sat Publishing Institute.

Srong, B., Devault, C., \& Cohen, T. F. (2011). The Marriage and Family Experience: Intimate Relationships in a Changing Society (11th ed.). USA: Wadsworth General Learning.

Troupe, F. Y. (2008). Marital Conflict: A Longitudinal Study. Requirements for the Degree of Doctor of Philosophy, Tallahassee, FL: The Florida State University. 
Submit or recommend next manuscript to SCIRP and we will provide best service for you:

Accepting pre-submission inquiries through Email, Facebook, LinkedIn, Twitter, etc. A wide selection of journals (inclusive of 9 subjects, more than 200 journals)

Providing 24-hour high-quality service

User-friendly online submission system

Fair and swift peer-review system

Efficient typesetting and proofreading procedure

Display of the result of downloads and visits, as well as the number of cited articles Maximum dissemination of your research work

Submit your manuscript at: http://papersubmission.scirp.org/

Or contact aasoci@scirp.org 